\title{
Mechanical Ventilation
}

National Cancer Institute

\section{Source}

National Cancer Institute. Mechanical Ventilation. NCI Thesaurus. Code C70909.

A method to mechanically assist or replace spontaneous breathing in patients by use of a powered device that forces oxyg enated air into the lungs. 